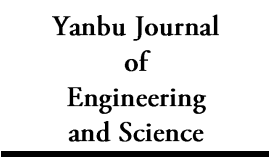

ISSN: 1658-5321
Vol. 2, April $2011(1432 \mathrm{H})$

www.yic.edu.sa/yjes

\title{
DSP-BASED CONTROL OF BOOST PFC AC-DC CONVERTERS USING PREDICTIVE CONTROL
}

\author{
H.Z.Azazi ${ }^{1}$, E. E. EL-Kholy ${ }^{2}$, S.A.Mahmoud ${ }^{1}$ and S.S.Shokralla ${ }^{1}$ \\ ${ }^{1}$ Electrical Engineering Department, Faculty of Engineering, Menoufiya University, Shebin El-Kom, Egypt \\ ${ }^{2}$ Electrical Engineering Department, Faculty of Engineering at Rabegh, King Abdulaziz University, Saudi Arabia \\ Email:Dr_hn1984@yahoo.com
}

\begin{abstract}
For digital power-factor correction (PFC) control methods, the duty cycle is calculated in every switching period. One main implementation barrier is the limited switching frequency, due to the limited processor speed. In this paper a predictive digital PFC control method is proposed to solve this problem. The proposed control method generates all the duty cycles in advance, based on the reference current and sensed inductor current, input voltage and output voltage. It requires only one multiplication and three addition operations for digital implementation, so that the proposed PFC control method can be implemented (by using a low cost DSP or microprocessor to achieve high switching frequency). A power factor correction rectifier, that requires a current control with a rectified sinusoidal reference, is controlled using three methods: i) Average current mode control ii) Hysteresis control iii) Proposed predictive control. All these controllers are implemented on a digital platform. Simulation and experimental results show that predictive control has low THD, high PF, lower cost and better performance than the others control methods (due to its lower calculation requirement). Also, sinusoidal input current can be achieved under a non-sinusoidal input voltage condition for predictive control only.
\end{abstract}

KeYwORDs: Converter control, Power factor correction, Total harmonic distortion (THD), Digital control

\section{INTRODUCTION}

Power factor correction (PFC) converters are widely used nowadays. These converters aim to increase the power factor (PF) and decrease the total harmonic distortion (THD) of its input current. International standards, as the IEC 61000-3-2, restrict the maximum allowed THD for the current drained from the electric system [1-3]. The boost converter with digital controller is one of the most suitable for this purpose [4-5].

The analog control has been the conventional method of power factor correction (PFC) in switched mode power supplies (SMPS). The emergence of powerful, low cost microprocessors, digital signal processors (DSP) and field programmable gate array (FPGA) have made it possible for the digital control to become a competitive option [6-8]. However, most of the existing digital PFC control methods are based on conventional analog control laws. They basically implement the analog control laws in a digital format [2,9-10]. In conventional digital implementation, multiplication and division operations are implemented by the software. Because all the calculations, are executed in 
every switching period, the implementation of conventional methods requires a high speed digital controller [2].

With the development of digital technique, many advanced control strategies can be implemented by digital processors. Digital control is the trend in switching mode power supply applications; however, it still faces several techniques in the digital implementation of high switching frequency power supplies, including AC-DC and DCDC converters. For AC-DC converters with power factor correction, there are several disadvantages in the existing digital control PFC implementation based on conventional current mode control, such as high computation requirements, limited switching frequency and high cost $[9,11]$. In order to take full advantage of digital techniques, predictive control methods are being explored and implemented in digital controlled PFC [12-13].

References [14] and [15] present a digital predictive deadbeat control, that does not update the duty cycle in every switching cycle, because the DSP is not fast enough to complete all the calculations. In the predictive dead-beat (PDB) control, the duty cycle, $d(n)$, is calculated and updated once in every control period, which is several, or several tens of switching cycles. However, this control method works only under the ideal input situation, because the input voltage is determined by a look-up table. In addition, the harmonic in the line current is increased in the Boost PFC implementation controlled by that method.

Digital current program control, using another predictive algorithm was presented in Ref. [13]. In Ref. [13], the duty cycle, $d(n+1)$, was calculated based on the value of the present duty cycle, $d(n)$, and sensed inductor current, input voltage and output voltage.
The problem is that, the duty cycle calculation requires the duty cycle value in the previous switching cycle. Therefore, if there is an error in the calculation value of $d(n)$, this error will affect the calculation value of $d(n+1)$.

Although so many digital PFC control methods were presented in the reference papers, there are still several problems that needed to be solved for digital implementations. In digital control PFC, the problems are mainly related to the following aspects: high calculation required in one switching cycle, high cost of the digital controller and limited switching frequency compared with analog control.

In this paper, in order to achieve higher switching frequency with low cost, low calculation requirements and better performance than the conventional PFC control methods a predictive digital PFC control is proposed. One of the significant characteristics of the proposed digital PFC control method is that the switching frequency is not directly dependent on the speed of the DSP. Therefore, a low-cost $\mathrm{DSP} /$ microprocessor could be used to control the switch operating at a high switching frequency.

In order to evaluate predictive control as an alternative to control a PFC rectifier, two classical input current control methods are considered: average current mode control and hysteresis control.

\section{DIGITAL PFC CONTROL BASED ON AVERAGE CURRENT MODE CONTROL}

DSP control of a boost PFC based on average current mode control is illustrated in Fig 1. In the outer voltage loop, the output voltage is sensed and compared with the voltage reference. The error becomes the input of the voltage proportional-integral (PI) controller. 
The output of this PI controller is the scaling factor for the rectified voltage that is used as one of the inputs to the multiplier. The product of the scaling factor and the rectified voltage divided by the square of the root mean square (RMS) of input voltage is the current reference, $\mathrm{i}_{\text {ref. }}$ The inner current loop implements average current mode control to force the average inductor current to follow the reference current.

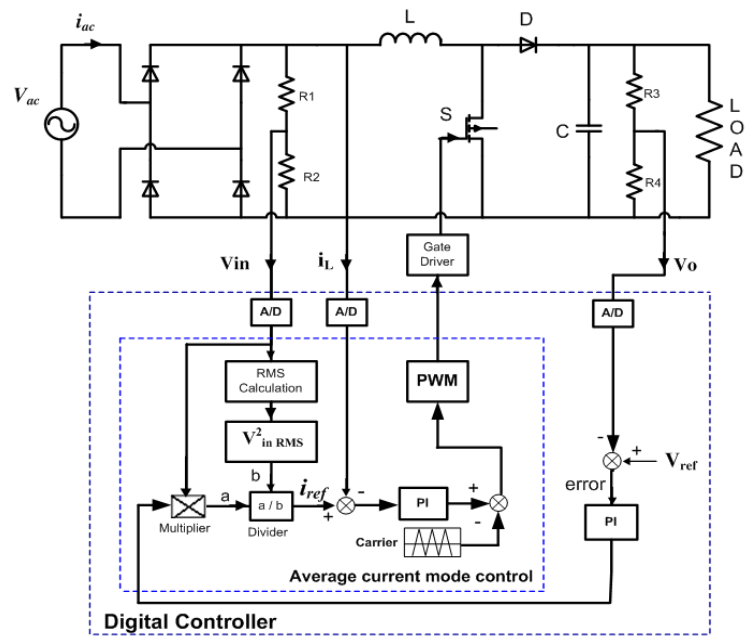

Fig.1. Digital control PFC implementation based on average current mode control.

In digital implementation for average current mode control, multiplication and division operations are implemented by the software. Because all the calculations, including multiplication and division, are executed in every switching period, the implementation requires a high speed digital controller.

The processes in a digital control PFC based on average current mode control include: output voltage samples, voltage error calculation, voltage PI controller, reference current controller (including two multiplication and one division), current error calculation, current PI controller and duty cycle calculations. Because this process is iteratively running in every switching cycle, a high performance DSP is needed. The average current mode control works well in analog controlled PFC systems, however, it is not suitable for digital control PFC implementations, because its high calculation requirements.

\section{HYSTERESIS CURRENT CONTROL}

This is a continuous current, variable switching frequency current control scheme. The boost inductor current is continuously compared with the reference current waveform (which is obtained from the voltage control loop) and the error signal (after amplification) is fed into a hysteresis comparator. When the actual inductor current goes above the reference current by the comparator hysteresis band, the comparator change its state to switch off the boost switch and the current ramp goes down. When the actual current goes below the reference current by the comparator hysteresis band, it changes state again and turns the boost switch on. Thus, the inductor current is always maintained within $\pm \mathrm{H}$, where $2 \mathrm{H}$ is the total hysteresis band. A simple diagram of a typical hysteresis current controller is shown in Fig.2.

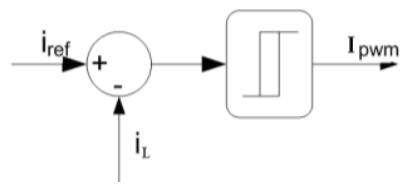

(a) Functional diagram.

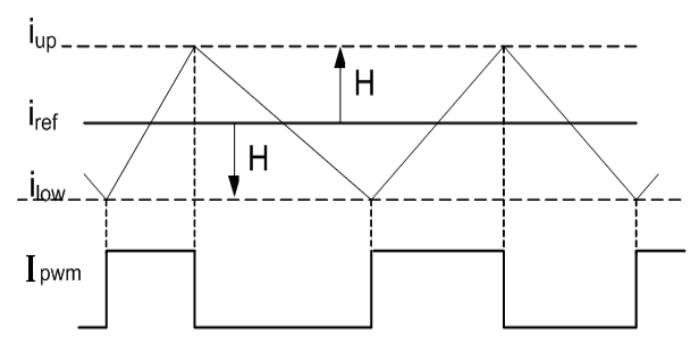

(b) Current and PWM waveforms.

Fig.2. General hysteresis current control scheme.

\section{PREDICTIVE ALGORITHM FOR BOOST CONVERTER}

The topology of Boost converter is shown in Figure 3. The proposed predictive PFC 
algorithm is developed based on the following assumptions: (1) Boost converter operates at continuous conduction mode; (2) The switching frequency is much higher than the line frequency. Therefore, the input voltage, $\mathrm{V}_{\text {in }}$, and output voltage, $\mathrm{V}_{0}$, can be assumed as constant during one switching cycle, $\mathrm{T}_{\mathrm{s}}$. Thus, when the switch $S$ is on or off, the boost converter is described by two modes of operation, as shown in Fig. 4.

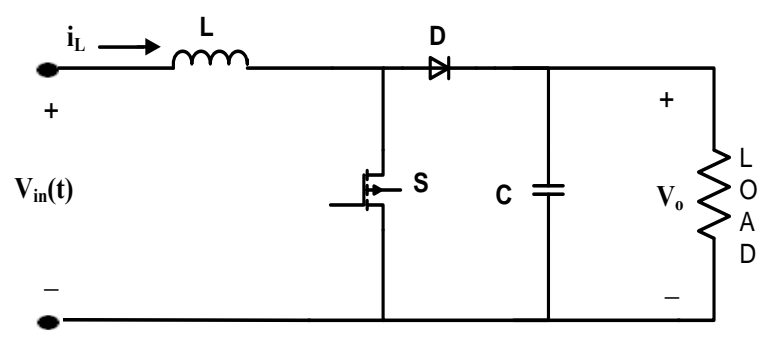

Fig.3. Boost converter topology.

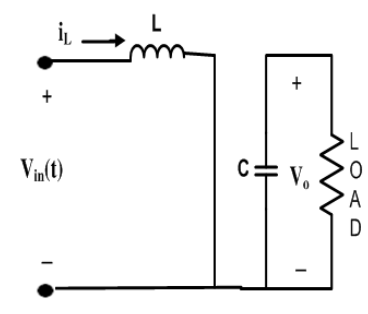

(a) Mode 1

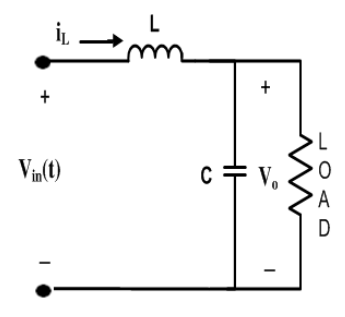

(b) Mode 2
Fig.4. Boost converter equivalent circuits.

When the switch is on, the inductor current, $\mathrm{i}_{\mathrm{L}}(\mathrm{t})$, can be expressed as:

$L \frac{d i_{L}}{d t}=V_{i n}(t)$ For $t(n) \leq t<t(n)+d(n) \cdot T_{s}$

When the switch is off, the inductor current, $\mathrm{i}_{\mathrm{L}}(\mathrm{t})$, can be expressed as:

$L \frac{d i_{L}}{d t}=V_{i n}(t)-V_{o}(t)$ For $t(n)+d(n) \cdot T_{s} \leq t<t(n+1)$

Where $V_{\text {in }}(t)$ is the input voltage, $\operatorname{Vo}(t)$ is the output voltage, $t(n)$ and $t(n+1)$ are the beginning instant of $\mathrm{n}^{\text {th }}$ and $(\mathrm{n}+1)^{\text {th }}$ switching cycle, $d(n)$ is the duty cycle in the $n^{\text {th }}$ switching cycle, and $T_{s}$ is the switching period.
Because the switching frequency is much higher than the line frequency, the differential equations (1) and (2) can be expressed as:

$$
\begin{aligned}
& L \frac{i_{L}\left(t(n)+d(n) \cdot T_{s}\right)-i_{L}(t(n))}{d(n) \cdot T_{s}}=V_{i n}(t(n)) \\
& L \frac{i_{L}(t(n+1))-i_{L}\left(t(n)+d(n) \cdot T_{s}\right)}{(1-d(n)) \cdot T_{s}}=V_{i n}(t(n))-V_{o}(t(n))
\end{aligned}
$$

Where $i_{L}[t(n)], i_{L}[t(n+1)]$ are the inductor current at the beginning of $n$th and $(n+1)^{\text {th }}$ switching cycles. The inductor current in one switching cycle is shown in Fig. 5.

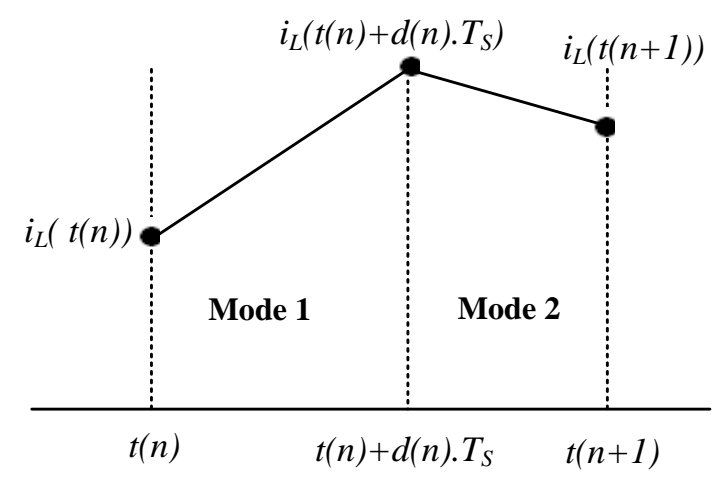

Fig.5. Inductor current in one switching cycle.

The inductor current at the switching off instant, $t(n)+d(n) T_{s}$, can be derived from equation (3) as:

$i_{L}\left(t(n)+d(n) \cdot T_{s}\right)=i_{L}(t(n))+\frac{1}{L} \cdot V_{i n}(t(n)) \cdot d(n) \cdot T_{s}$

The inductor current at the beginning instant of $(n+1)^{\text {th }}$ switching cycle , $t(n+1)$, can be derived from equation (4) as:

$i_{L}(t(n+1))=i_{L}\left(t(n)+d(n) \cdot T_{s}\right)$
$+\frac{1}{L} \cdot\left(V_{i n}(t(n))-V_{o}(t(n)) \cdot(1-d(n)) \cdot T_{s}\right.$

Substituting equations (5) and (6), the inductor current at the beginning instant of $(\mathrm{n}+1)^{\text {th }}$ switching cycle in terms of the inductor current at the beginning instant of nth switching cycle can be derived as: 
$i_{L}\left(t(n+1)=i_{L}(t(n))+\frac{1}{L} \cdot V_{i n}(t(n)) \cdot T_{s}\right.$

$-\frac{1}{L} V_{o}(t(n)) \cdot(1-d(n)) \cdot T_{s}$

The discrete form of equation (7) can be expressed as:

$i_{L}(n+1)=i_{L}(n)+\frac{V_{i n}(n) \cdot T_{s}}{L}-\frac{V_{o}(n) \cdot(1-d(n)) \cdot T_{s}}{L}$

The above equation indicates that the inductor current at the beginning of the next switching cycle is determined by the inductor current at the beginning of the present switching cycle, the input voltage, the output voltage and the duty cycle for the present switching cycle.

Equation (8) can be rewritten as

$d(n)=\frac{L}{T_{S}} \frac{i_{L}(n+1)-i_{L}(n)}{V_{o}}+\frac{V_{o}-V_{i n}(n)}{V_{o}}$

It is observed that the required duty cycle for the present switching cycle, $\mathrm{d}(\mathrm{n})$, can be determined based on the boost circuit parameters, the output voltage, the input voltage and the required inductor current.

In a properly designed AC-to-DC converter with PFC, $i_{L}(n+1)$, is forced to follow the reference current, $i_{\text {ref }}(n+1)$, which is a rectified sinusoidal waveform. $V_{o}$, is controlled to follow the reference voltage, $V_{\text {ref. }}$.

Substituting $\mathrm{i}_{\text {ref }}(\mathrm{n}+1), V_{\text {ref }}$ for $\mathrm{i}_{\mathrm{L}}(\mathrm{n}+1)$ and $V_{o}$ in equation (9), the duty cycle can be derived as:

$d(n)=\frac{L}{T_{S}} \frac{i_{r e f}(n+1)-i_{L}(n)}{V_{r e f}}+\frac{V_{r e f}-V_{i n}(n)}{V_{r e f}}$

The reference current, $\mathrm{i}_{\text {ref }}$ is determined as:

$$
\mathrm{i}_{\text {ref }}(\mathrm{n}+1)=\mathrm{K}_{\mathrm{PI}} \cdot \mid \sin \left(\omega_{\text {line. }} \mathrm{t}(\mathrm{n}+1) \mid\right.
$$

$K_{P I}$ is the peak value of reference current, which is the output of the voltage loop controller, (is the rectified sinusoidal waveform), it can be determined by a look-up table in digital implementation or a resistor divider from the rectified input voltage.

The block diagram of the digital controlled boost PFC based on the Predictive control algorithm is shown in Fig. 6.

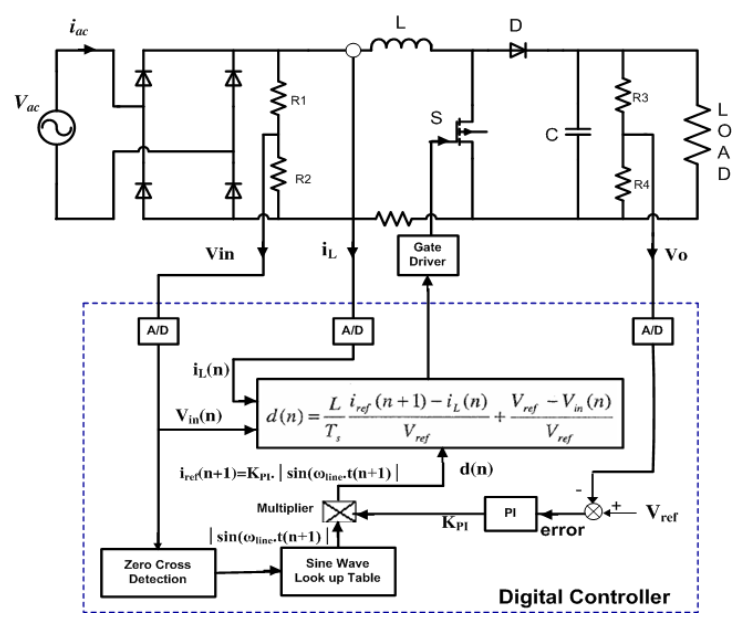

Fig.6. Digital implementation of proposed Predictive control.

\section{SIMULATION RESULTS}

The control algorithms of the current control methods have been developed and implemented on the MATLAB/SIMULNK programming environment. The purpose of this simulation is to show the effectiveness of the different control strategies for PFC circuit and in reducing the supply current harmonic distortion.

The PFC boost converter is designed with the following specifications: ac input voltage, 220 $\mathrm{V}$; dc output voltage, $330 \mathrm{~V}$; load resistance, $172 \Omega$; line frequency $(f), 50 \mathrm{~Hz}$; inductor $(L), 10 \mathrm{mH}$ and dc link capacitor $(C), 5000$ $\mathrm{uF}$.

The steady state simulation results of input current and its spectrum for all current control methods are shown in Fig.7 and Fig. 8 respectively. It is shown that, the predictive current control simulation shows smaller harmonic content of the three control methods, and an input current is nearly sinusoidal. The power factor for average 
current mode control, hysteresis current control and predictive current control are $0.9889,0.996$ and 0.9998 respectively.

Figure 9 shows the steady state input voltage $\left(\mathrm{V}_{\mathrm{i}}\right)$ and current $\left(\mathrm{i}_{\mathrm{i}}\right)$ for ideal input voltage for the three control methods. It is shown that, the input current in phase with the input voltage for three control methods. The rectified voltage $\left(V_{R}\right)$, rectified current $\left(i_{R}\right)$ and reference current $\left(i_{\text {ref }}\right)$ under the steady state are shown in Fig. 10 for three current methods. The input current waveforms under a distorted input voltage condition are shown in Fig. 11. Results show that sinusoidal input current waveform can be achieved under a non-sinusoidal input voltage condition for predictive current control only. The dynamic performance under the transient state for a step change in load is shown in Fig. 12. It is shown that, dynamic response for the predictive current control is faster than other two methods.

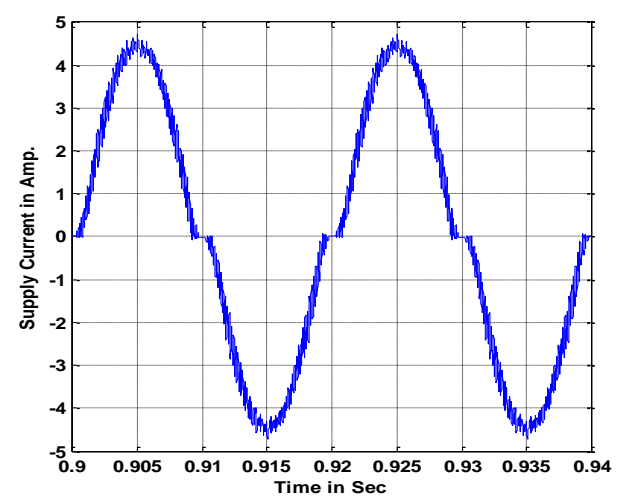

(a) Average current mode control.

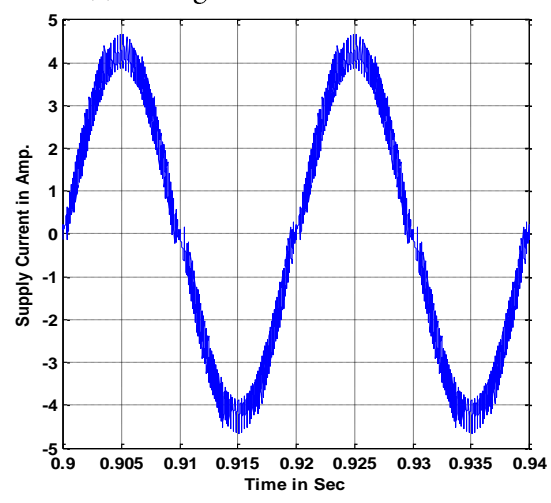

(b) Hysteresis current control.

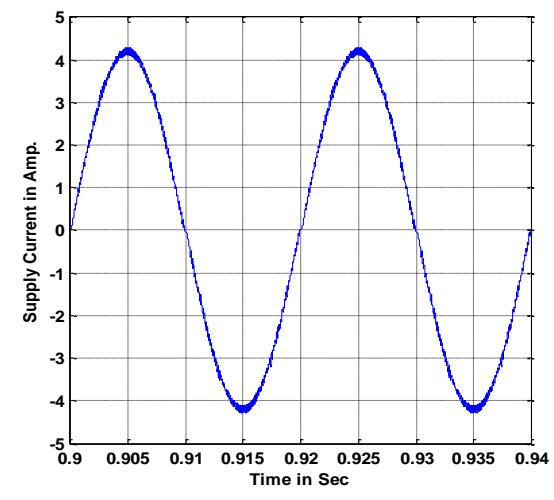

(c) Predictive current control.

Fig.7. Input current waveform .

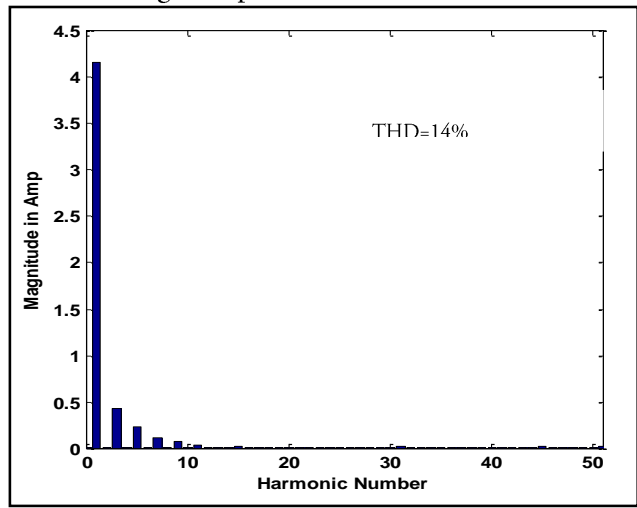

(a) Average current mode control.

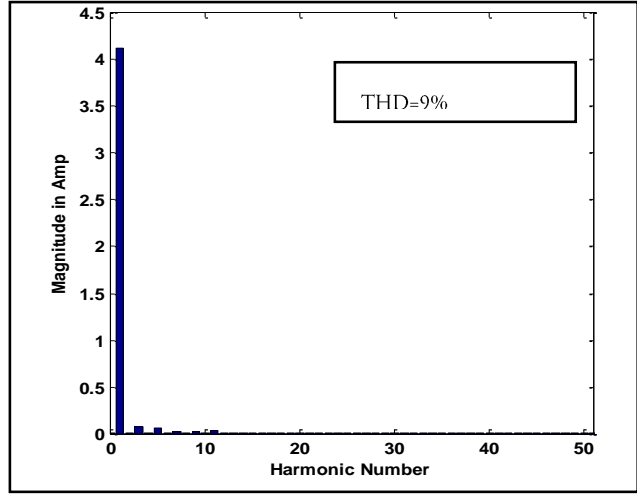

(b) Hysteresis current control.

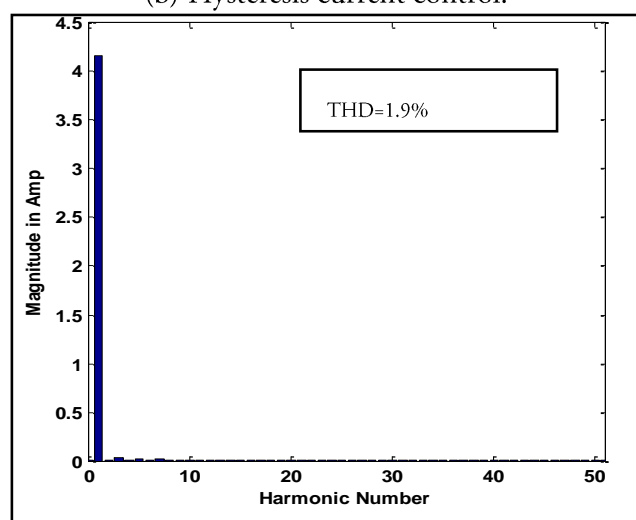

(c) Predictive current control. Fig.8. Total harmonic distortion. 


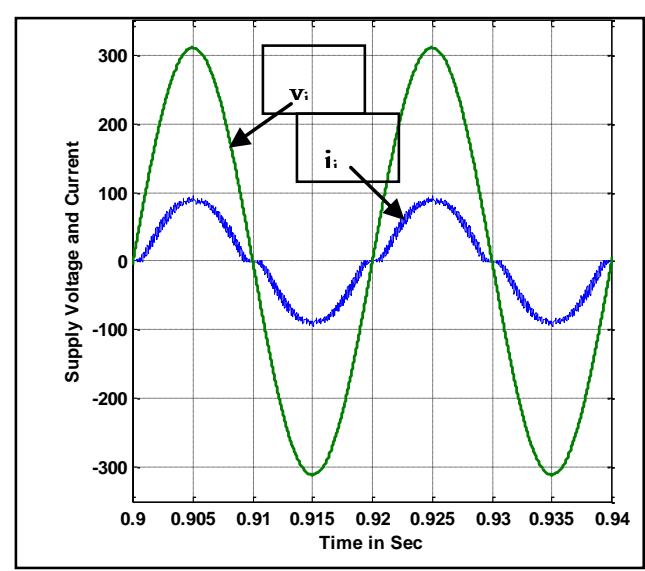

(a) Average current mode control.

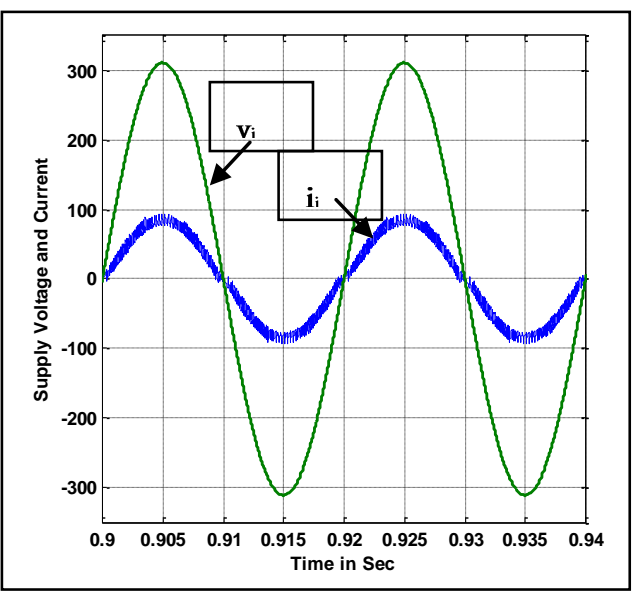

(b) Hysteresis current control.

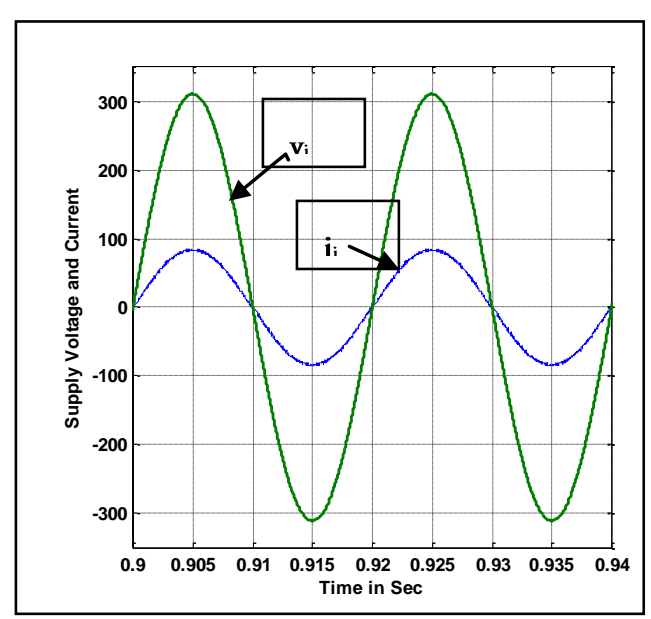

(c) Predictive current control.

Fig.9. Input voltage and current for ideal supply voltage.

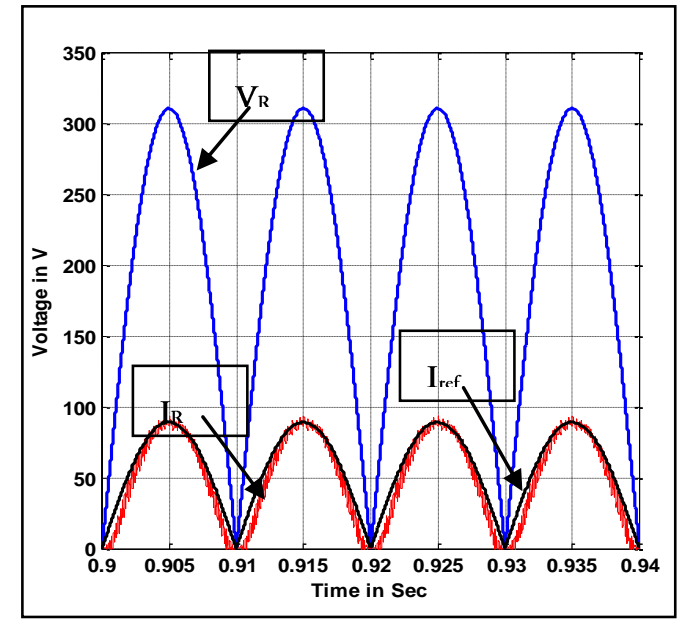

(a) Average current mode control.

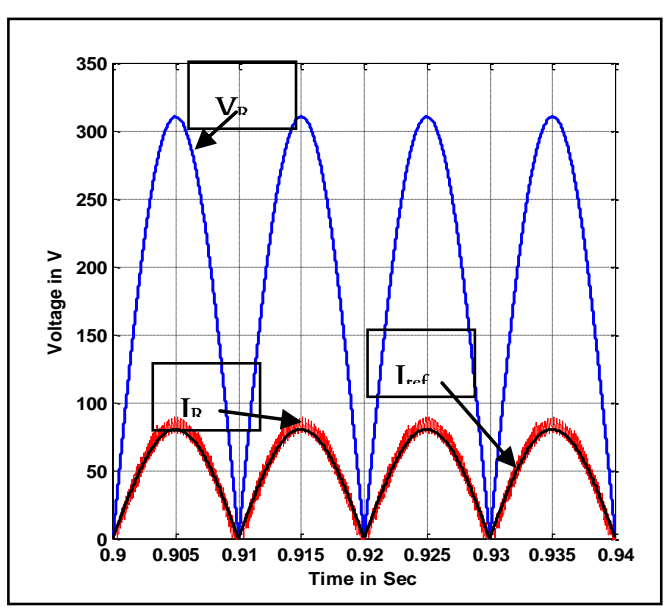

(b) Hysteresis current control.

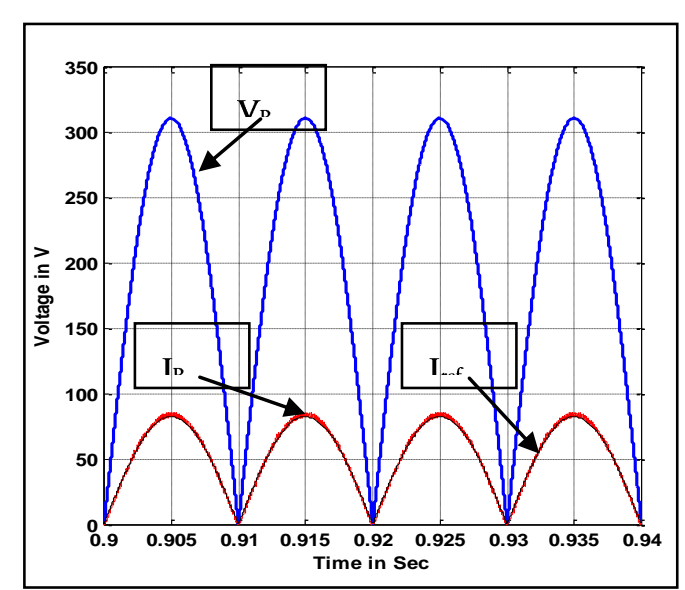

(c) Predictive current control.

Fig.10. Rectified voltage, rectified current and reference current. 


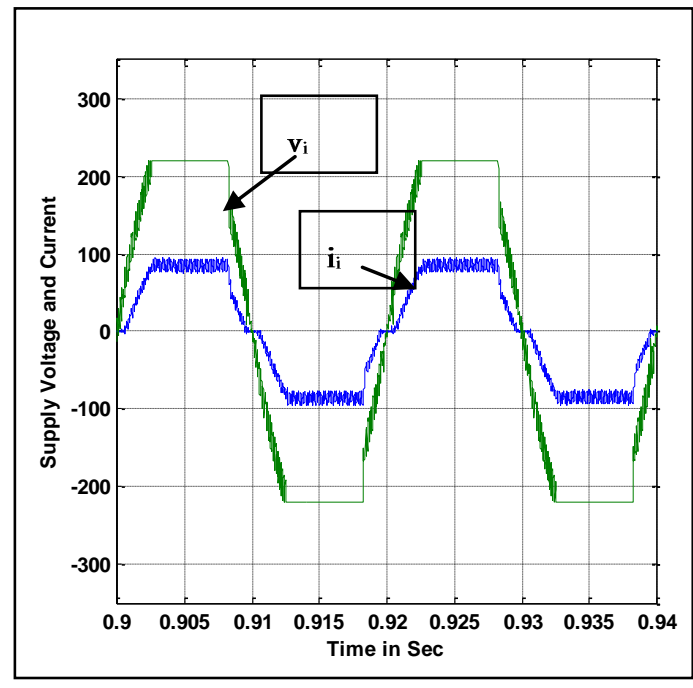

(a) Average current mode control.

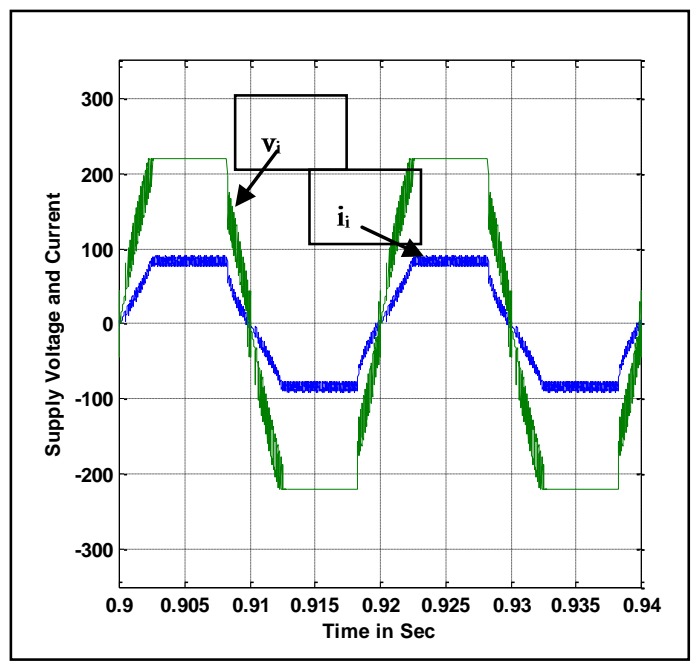

(b) Hysteresis current control.

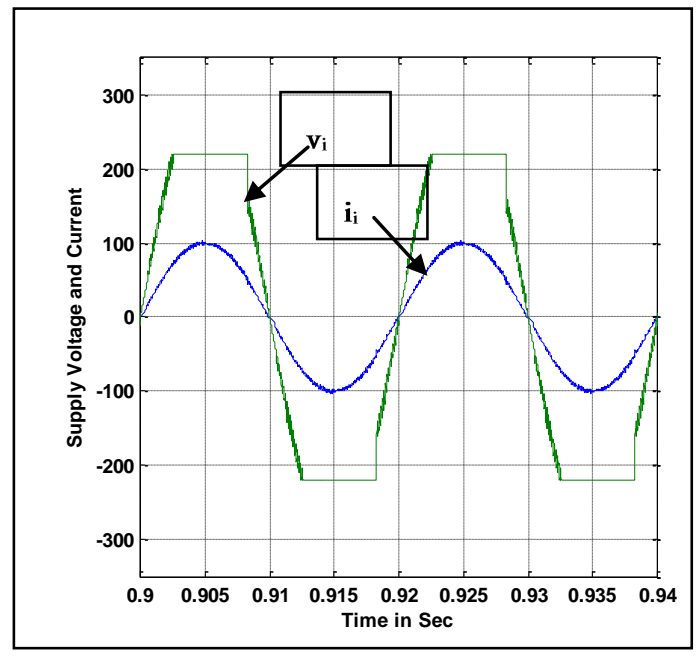

(c) Predictive current control.

Fig.11. Input voltage and current for distorted input voltage.

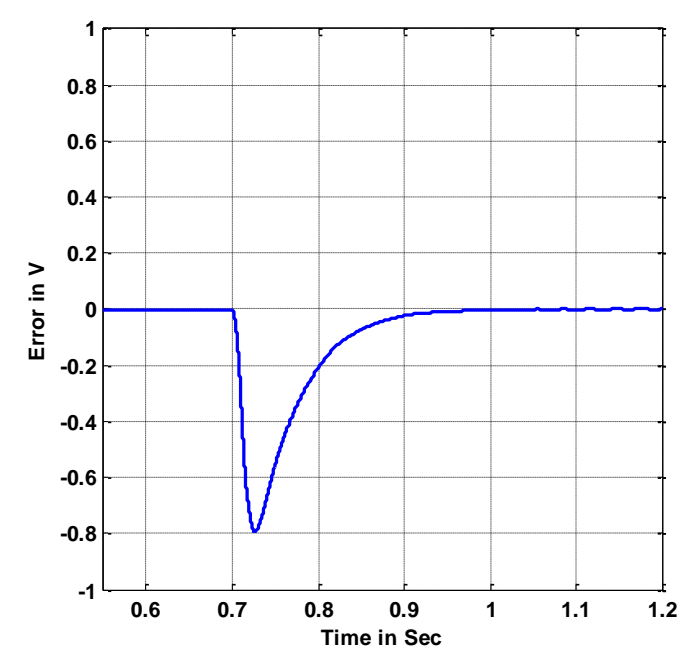

(a) Average current mode control.

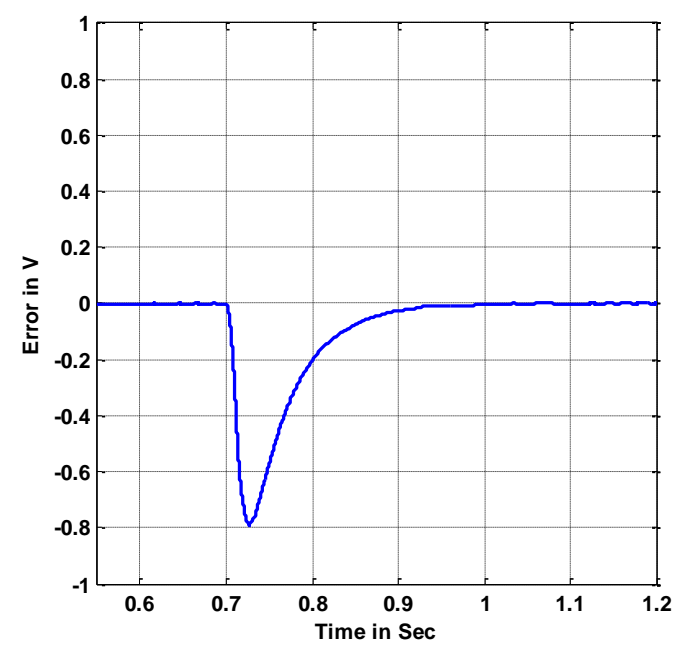

(b) Hysteresis current control.

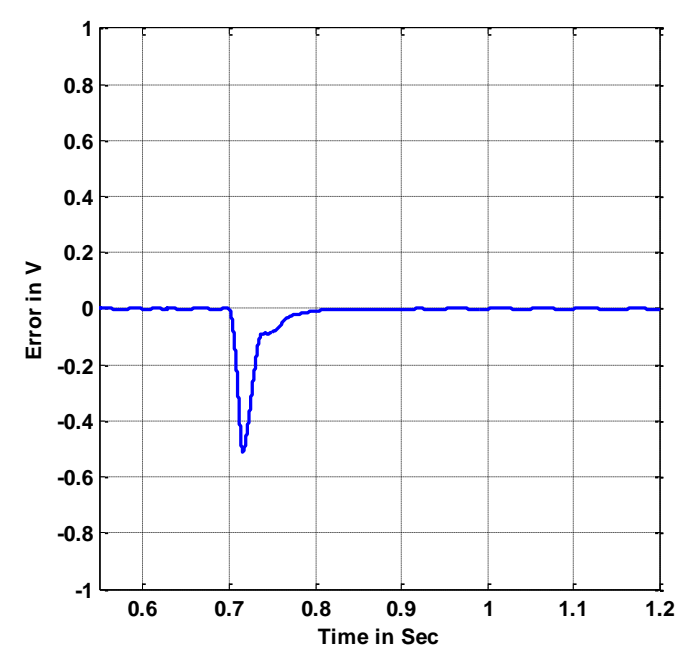

(c) Predictive current control.

Fig.12. Transient response for step change in load. 


\section{EXPERIMENTAL RESULTS}

A prototype of boost PFC controlled by a DSP 1104 evaluation board was built and tested in the laboratory in order to verify the proposed digital control PFC strategy. The steady state experimental results of input current for all current control methods are shown in Fig.13. It is shown that, the predictive current control shows smaller harmonic content of the three control methods, and an input current is nearly sinusoidal because the high switching frequency. Figure 14 shows the steady state input voltage and current for the three control methods. It is shown that, the input current in phase with the input voltage for three control methods. The rectified current and reference current under the steady state are shown in Fig. 15 for three current methods.

The dynamic performance under the transient state for a step change in load is shown in Fig. 16. It is shown that, dynamic response for the predictive current control is faster than other two methods.

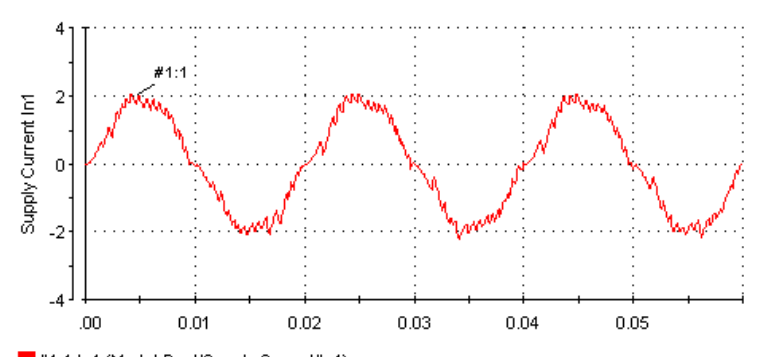

(a) Average current mode control.

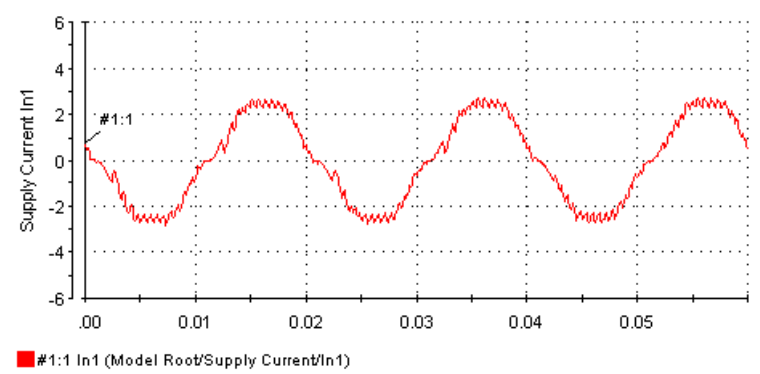

(b) Hysteresis current control.

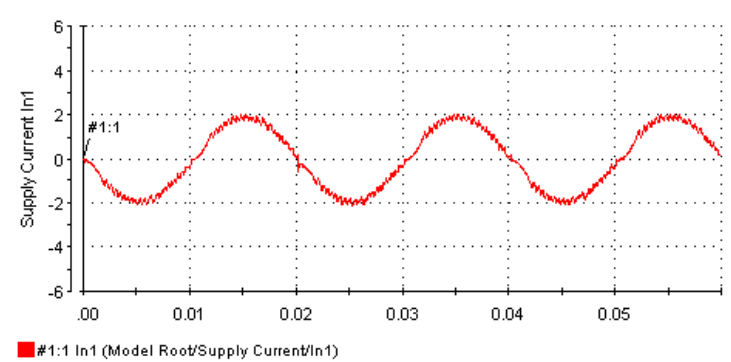

(c) Predictive current control.

Fig.13. Experimental input current waveforms .

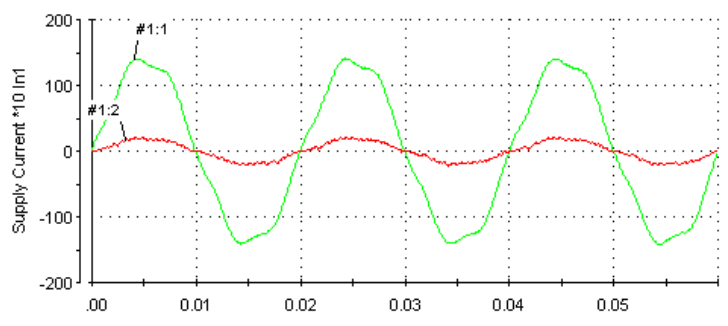

\#1:1 In1 (Model Root'Supply Voltagein/ln 1 )

(a) Average current mode control.

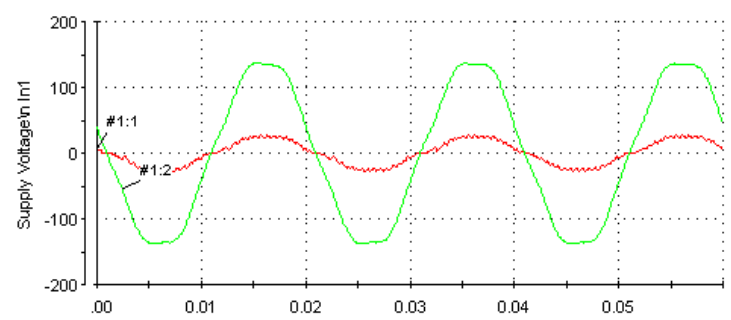

*1:1 In 1 (Model Root'Supply Current ${ }^{5} 5 / \ln 1$ )

(b) Hysteresis current control.

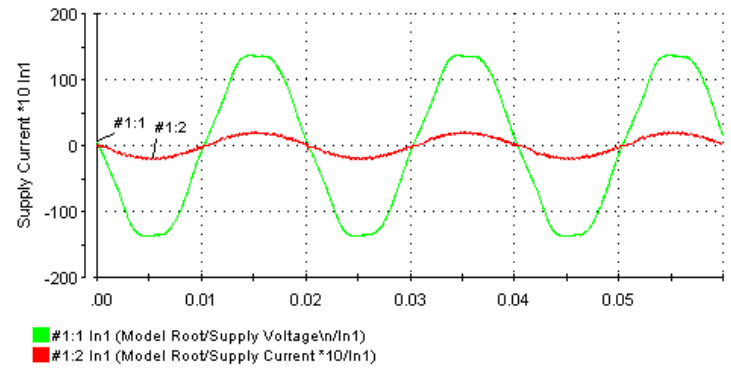

(c) Predictive current control.

Fig.14. Experimental input voltage and current waveforms.

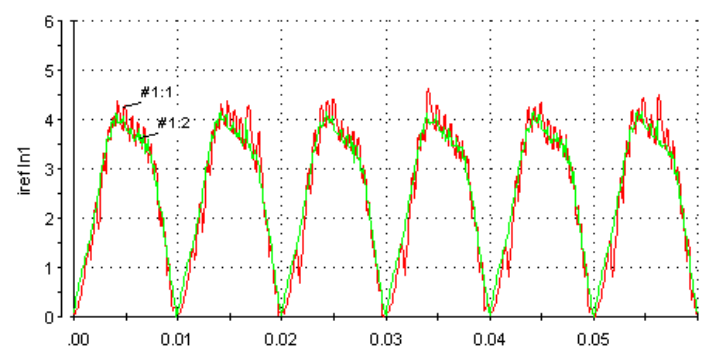

\#1:1 $\ln 1$ (Model Rootirectifier current'ln 1 )

(a) Average current mode control. 


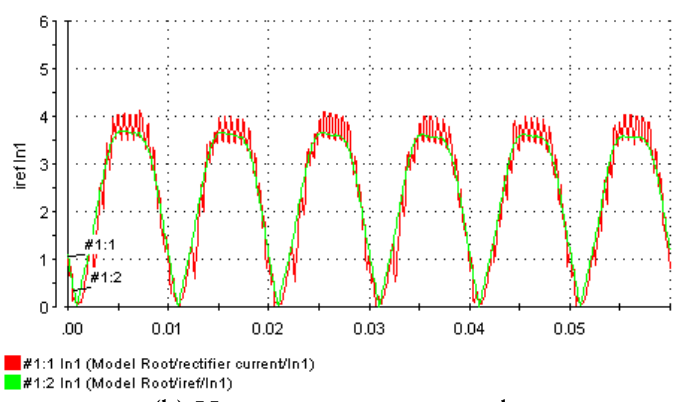

(b) Hysteresis current control.

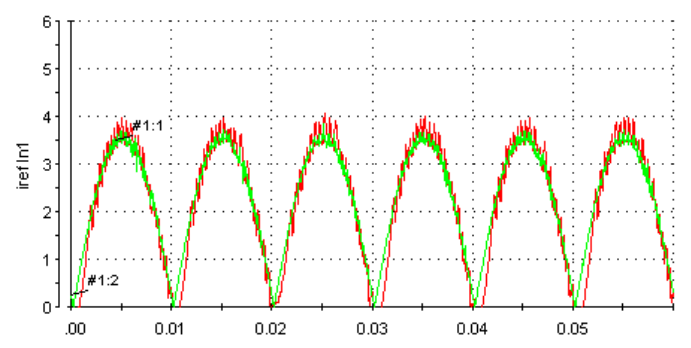

E $\# 1: 1 \ln 1$ (Model Rootirectifier currentin 1 )

(c) Predictive current control.

Fig.15. Experimental rectified and reference current waveforms.

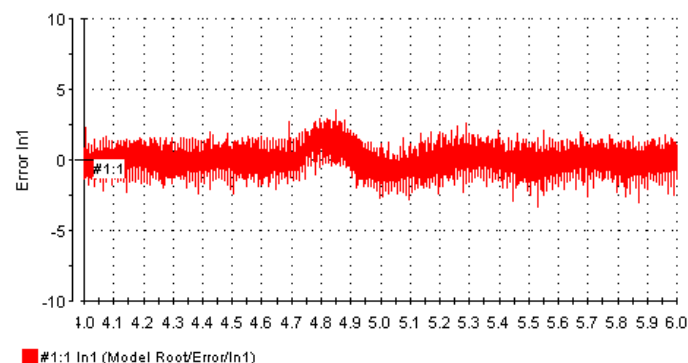

(a) Average current mode control.

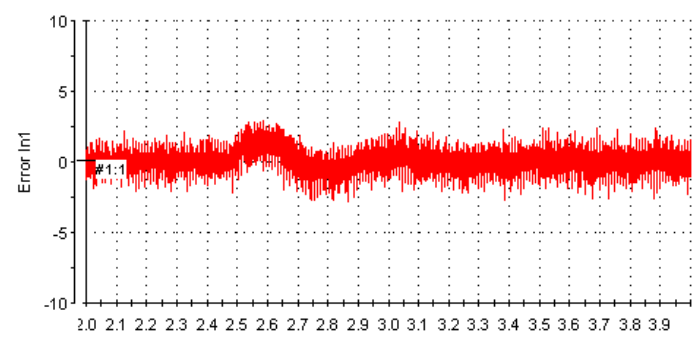

\# $1: 1 \ln 1$ (Model Root'Error'ln 1 )

(b) Hysteresis current control.

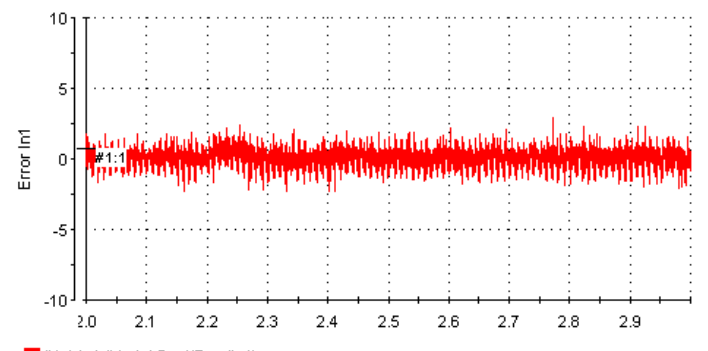

(c) Predictive current control.

Fig.16. Experimental transient response for step change in load.

\section{CONCLUSION}

One disadvantage of the existing digital PFC control methods is that the switching frequency is limited due to the processing time of the DSP. Predictive digital PFC control method was proposed in this paper to solve this problem. The proposed control method generates all the duty cycles in advance based on the reference current and sensed inductor current, input voltage and output voltage. It requires only one multiplication and three addition operations for digital implementation, so that the proposed PFC control method can be implemented by a low cost DSP or microprocessor to achieve high switching frequency. Other two control methods have been used in order to evaluate predictive control as an alternative to control a PFC converter. The predictive control method is simpler than other commonly used methods. Simulation and experimental results showed that predictive PFC control has low THD, high $\mathrm{PF}$, lower cost and better performance than the other control methods due to its lower calculation requirement. Also, sinusoidal input current can be achieved under a non-sinusoidal input voltage condition for predictive control only. The predictive digital PFC control method can achieve good dynamic performance for load change.

\section{REFERENCES}

[1] Compliance Testing to the IEC 1000-3-2 (EN 61000-3-2) and IEC 1000-3-3 (EN 61000- -3) Standards, Application Note 1273, Hewlett Packard Co., December, 1995.

[2] Wanfeng Zhang, Guang Feng, Yan-Fei Liu and Bin Wu, "New Digital Control Method for Power Factor Correction", IEEE Transactions on Industrial Electronics, Vol. 53 (3), pp. 987-990, 2006. 
[3] Supratim Basu and Math.H.J.Bollen, "A Novel Common Power Factor Correction Scheme for Homes and Offices," IEEE Transactions on Power Delivery, Vol.20(3), July 2005.

[4] Roggia L., Beltrame F., Baggio J.E. and Pinheiro J.R.,"Digital control system applied to a PFC boost converter operating in mixed conduction mode", in Proc. IEEE Appl. Power Electron. Conf., 2009, pp. $698-704$.

[5] Yu-Tzung Lin and Ying-Yu Tzou, "Digital Control of Boost PFC AC/DC Converters with Low THD and Fast Dynamic Response," IEEE IPEMC Conf. Rec., 2009, pp. 672 - 1677.

[6] Azcondo F.J., Castro A.de, Lopez V.M. and Garcia O., "Power Factor Correction without Current Sensor based on Digital Current Rebuilding," IEEE Transaction on Power Electronics, Vol. 25, 2009, pp. 1527 - 1536

[7] Rao V.M., Jain K.A., Reddy K.K. and Behal A., "Experimental Comparison of Digital Implementations of Single-Phase PFC Controllers," IEEE Transaction on Power Electronics, Vol. 55 (1), 2008, pp.67-78.

[8] Chen F. and Maksimović D., "Digital Control for Improved Efficiency and Reduced Harmonic Distortion over Wide Load Range in Boost PFC Rectifiers," in Proc. IEEE Appl. Power Electron. Conf. Expo., Washington, DC, Feb. 2009, pp. 760-766.

[9] Fu M. and Chen Q., "A DSP base controller for power factor correction in a rectifier circuit," in Proc. IEEE Appl. Power Electron. Conf., 2001, pp. 144-149.

[10] Prodic A., Maksimovic D., and Erikson R.W., "Dead-Zone digital controller for improved dynamic response of power factor correction," in Proc. IEEE Appl. Power Electron Conf., 2003, pp.382-388.

[11] Buso S., Mattavelli P., "Simple Digital Control Improving Dynamic Performance of Power Factor Preregulators", IEEE Transaction on Power Electronics, Vol. 13(5), Sep. 1998, pp.814-823.

[12] Roggia L., Baggio J.E. and Pinheiro J.R., "Predictive Current Controller for a Power Factor Correction Boost Converter Operating in Mixed Conduction Mode," IEEE EPE Conf., 2009.
[13] Chen J., Prodić A., Erickson R.W. and Maksimović D., "Predictive Digital Current Programmed Control," IEEE Transaction on Power Electronics, Vol. 18(1), 2003, pp.411-419.

[14] Bibian S. and Jin H., "Digital control with improved performance for boost power factor correction circuits," in Proc. Appl. Power Electron. Comf., 2001, pp137-143.

[15] Bibian S. and Jin H., "High performance predictive dead-beat controller for DC power," in proc. Appl. Power Electron. Conf., 2001, pp67-73. 


\title{
تصحيح معامل القدرة بإعتماد معالج الإشارة الرقمي للمحولات العكسية (تيار متردد-تيار مستمر) مستخدماً طريقة

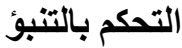

\author{
هيثم عزازي1، علوي الخولي، صبري عبداللطيف1، شكري سعد1 \\ قسم الهندسة الكهربائية، كلية الهندسة، جامعة المنوفية، جمهورية مصر العربية \\ 2 قسم الهندسة الكهربائية، كلية الهندسة برابغة الئنة جامعة الملك عبدالعزيز ، المملكة العربية السعودية العية
}

(الملخص:

عند إستخدام طرق التحكم لتصحيح معامل القدرة فإنه يتم حساب دورة الخدمة لكل مرحلة تبديل، ومن ضمن أهم الصعوبات أن تردد التبديل محدود بالنسبة لسر عة المعالج الرقمي. و المقترح في هذا البحث در اسة طريقة التحكم بالتتبؤ لتصحيح معامل القدرة لحل المشكلة. وتقوم طريقة التحكم المقترحة على توليد كل دورات الخدمة مقدماً بناءً على التيار الأصلي و المستشعر، جهد التغذية وجهد الخروج. وسوف يتم إستخدام معالج الإشارة الرقمي او المعالج الدقيق للحصول على تردد تبديل عالي. يتم التحكم في مقوم تصحيح معامل القدرة الذي يحتاج إلى تيار

$$
\text { تحكم مقوم عن طريق ثناث طرق: 1 } 1 \text { طريقة التيار المتوسط }
$$

2. طريقة الرجو عية المغناطيسية (Hystersis)

3. طريقة التنبؤ

تمت در اسة الثلاثة طرق نظرياً و عملياً وأكدت النتائج أن طريقة التنبؤ تعطي أفضل النتائج. 